\title{
PENYESUAIAN DIRI DOSEN SENIOR DALAM PEMBELAJARAN JARAK JAUH DI MASA COVID-19
}

\author{
Adita Putri Vicianti ${ }^{1}$, Hanifah ${ }^{2}$ \\ ${ }^{1}$ Fakultas Psikologi, Universitas Padjadjaran \\ Email: adita19001@mail.unpad.ac.id \\ ${ }^{2}$ Fakultas Psikologi, Universitas Padjadjaran \\ Email: hanifah@unpad.ac.id
}

\begin{abstract}
Distance Learning which is the impact of the COVID-19 pandemic is a necessity that must be carried out by all lecturers. Distance learning based on digital technology has a serious impact on senior lecturers over the age of 50 with limited digital knowledge and skills. The purpose of this study is to describe the adjustment of senior lecturers in distance learning which includes the absence of excessive emotions, the absence of psychological mechanisms, and feelings of personal frustration, rational judgment and self-direction, the ability to learn, the ability to use past experiences. past, and a realistic and objective attitude (Schneiders, 1999). Qualitative methods and phenomenological approaches with thematic analysis techniques are used in this study. Through telephone interviews and video calls with 4 senior lecturers who have worked for more than 30 years, it was obtained that senior lecturers were able to manage emotions calmly in the face of changing learning methods to distance learning due to the COVID19 pandemic. Most of the lecturers take into consideration in overcoming difficulties, they also have a desire to learn new things and try to learn other online media platforms because the previous ones were deemed ineffective. The two lecturers carried out a psychological rationalization mechanism due to the difficulty in adjusting to the distance learning. All lecturers are not frustrated because there is no longer urgency to get certain achievements as lecturers at their age, all lecturers also say positive things about distance learning and state that blended learning can be used for the teaching process in the future.
\end{abstract}

Keyword: Adjustment, senior lecturer, distance learning, COVID-19

\begin{abstract}
ABSTRAK
Pembelajaran Jarak Jauh (PJJ) yang merupakan dampak dari pandemi COVID-19 menjadi sebuah keniscayaan yang harus dilakukan oleh semua dosen. PJJ yang berbasiskan teknologi digital membawa dampak yang cukup serius bagi dosen senior yang berusia diatas 50 tahun dengan pengetahuan dan keterampilan digitalnya terbatas. Tujuan penelitian ini adalah untuk menggambarkan penyesuaian diri dosen senior dalam pembelajaran jarak jauh yang meliputi ketiadaan emosi yang berlebihan, ketiadaan mekanisme psikologis, dan perasaan frustrasi pribadi, pertimbangan rasional dan kemampuan mengarahkan diri (self-direction), kemampuan untuk belajar, kemampuan menggunakan pengalaman masa lalu, dan sikap realistik dan objektif (Schneiders, 1999). Metode kualitatif dan pendekatan fenomenologis dengan teknik thematic analysis digunakan dalam penelitian ini. Melalui wawancara telepon dan video call terhadap 4 dosen senior yang sudah bekerja lebih dari 30 tahun, diperoleh gambaran bahwa para dosen senior mampu mengelola emosi dengan tenang dalam menghadapi perubahan metode pembelajaran menjadi PJJ akibat pandemi COVID-19. Sebagian besar dosen melakukan pertimbangan dalam mengatasi kesulitan, mereka juga memiliki keinginan untuk belajar hal baru dan mencoba mempelajari platform media online lainnya karena yang sebelumnya dirasa tidak efektif. Kedua dosen melakukan mekanisme psikologis rasionalisasi akibat kesulitan menyesuaikan dengan PJJ. Seluruh dosen tidak mengalami frustrasi karena tidak ada lagi urgensi untuk mendapatkan pencapaian tertentu sebagai dosen di usia mereka, seluruh dosen juga menyatakan hal yang positif terkait PJJ dan menyatakan bahwa blended learning dapat digunakan untuk proses pengajaran ke depannya.
\end{abstract}

Kata Kunci: Penyesuaian diri, dosen senior, pembelajaran jarak jauh, COVID-19

\section{PENDAHULUAN}

Latar Belakang

Pandemi COVID-19 adalah krisis kesehatan yang melanda hampir seluruh negara di dunia. Dr. Tedros sebagai chief WHO mengatakan bahwa virus ini telah menyebar dengan sangat cepat di beberapa negara dalam satu waktu yang banyak memakan korban (BBC, 2020). Virus corona telah 
masuk pada ratusan negara. Per April 2020, kasus yang telah terkonfirmasi sebanyak 3.726.292 di dunia. Di Indonesia sendiri virus corona baru masuk di awal tahun 2020. Hingga saat ini Indonesia memiliki kasus yang terkonfirmasi sebanyak 12.776 orang yang tercatat pada bulan April 2020 (WHO, 2020). Penyebaran COVID-19 yang pada mulanya sangat memberikan dampak pada kondisi kesehatan dan ekonomi dunia, kini dirasakan pula oleh dunia pendidikan. Perserikatan Bangsa-Bangsa (PBB) menangkap bahwa pendidikan menjadi salah satu sektor yang terdampak oleh COVID-19. Berdasarkan data yang dihimpun Organisasi Pendidikan, Keilmuan, dan Kebudayaan PBB (UNESCO), setidaknya ada 290,5 juta siswa di seluruh dunia yang aktivitas belajarnya menjadi terganggu akibat sekolah yang ditutup. Banyak negara yang memutuskan untuk menutup sekolah, perguruan tinggi, dan universitas untuk mencegah penyebaran virus corona. Kondisi COVID-19 tersebut memberikan dampak serius pada siswa, infrastruktur, dan organisasi pendidikan di seluruh dunia (Mailizar et al., 2020).

Kebijakan yang diambil oleh banyak negara termasuk Indonesia dengan meniadakan seluruh aktivitas pendidikan secara tatap muka, membuat pemerintah dan lembaga terkait harus menghadirkan alternatif dengan melakukan pembelajaran jarak jauh (PJJ). Perguruan tinggi yang sebelumnya melakukan metode tatap muka (face-to-face) saat perkuliahan maupun bimbingan skripsi dan kegiatan akademik lainnya kini perlu mengubahnya menjadi metode PJJ. Menteri Koordinator Bidang Pembangunan Manusia dan Kebudayaan (Menko PMK) Muhadjir Effendy menjelaskan semasa pandemi COVID-19 bukan hanya metode pembelajaran yang berubah dari tatap muka menjadi jarak jauh, tetapi juga para dosen harus kreatif dalam mengembangkan konten pembelajaran digital (Kominfo, 2020). Di dalam kelas, mahasiswa berinteraksi dengan sesama mahasiswa dan dosen, tetapi dalam sistem PJJ, ada keterpisahan jarak antara dosen dengan mahasiswa sehingga interaksi langsung antar individu tidak terjadi melainkan dimediasi oleh platform digital (Budiargo et al., 2020). Pada dasarnya sistem PJJ sendiri memiliki dua model, yaitu synchronous dan asynchronous. Syncronous dalam PJJ dapat memperoleh feedback secara langsung (Weiser et al., 2018) dan asyncronous menggunakan video atau modul berbentuk tutorial sehingga feedback tidak secara langsung didapat (Hrastinki, 2008).

Mulai pendidikan dasar hingga level perguruan tinggi dituntut mampu menyesuaikan dengan sistem pembelajaran jarak jauh berbasis teknologi internet (Purwanto et al., 2020). Di Indonesia sendiri pembelajaran jarak jauh menggunakan internet menjadi media yang efektif saat pandemi COVID-19. Institusi pendidikan di seluruh dunia memutuskan untuk menggunakan sumber daya teknis yang sudah tersedia untuk membuat materi pembelajaran online bagi siswa dari semua bidang akademik (Kaur, 2020). Komponen utama yang diperlukan saat pembelajaran daring yaitu desktop, laptop, smartphone dan internet. Beberapa aplikasi yang digunakan sebagai media pembelajaran daring di antaranya adalah Zoom, Google Classroom, Google Meet, Skype, Ruang guru, pengembangan aplikasi android atau mobile learning, dan lain-lain. Penggunaan aplikasi dipilih tergantung pada kemudahan akses dari masing-masing aplikasi yang memiliki keunggulan, yaitu pengguna gratis atau tidak berbayar, kelengkapan fitur aplikasi yang memudahkan pembelajaran, dan lain-lain (Sauri et al., 2020)

Dalam perguruan tinggi, dosen sebagai seorang pengajar kerap disebut sebagai Ilmuwan karena kapasitas ilmu yang ia miliki. Lamanya menjadi pengajar di perguruan tinggi akan membedakan status, golongan dan kepangkatannya. Golongan dan kepangkatan seorang dosen akan menentukan statusnya di antara dosen-dosen lainnya, yaitu sebagai dosen senior dan dosen junior atau dosen muda. Khusus di perguruan tinggi, usia kerja pengajarnya dapat mencapai usia 65 tahun atau bahkan 70 tahun. Menurut Ghufron sebagai Direktur Jenderal Sumber Daya Iptek dan Dikti, dosen yang berusia diatas 60 tahun merupakan kategori baby boomers yang sulit beradaptasi 
dengan kemajuan teknologi (Ghufron dalam PikiranRakyat, 2018). Menjadi dosen senior selama puluhan tahun memiliki peranan yang berbeda dengan dosen junior. Hal tersebut dikarenakan dosen senior telah menjadi pembina bagi para dosen junior yang masih belum memiliki pengalaman sebanyak dosen senior. Dosen senior membina dosen junior dalam hal materi pembelajaran, penelitian dan lain sebagainya. Dengan demikian dosen junior akan banyak belajar kepada dosen senior terkait materi pembelajaran, metode pembelajaran dan sebagainya. Sementara itu dosen junior adalah pendidik dalam kategori milineal dianggap lebih mudah beradaptasi dengan teknologi karena sudah akrab dengan dunia digital (Ghufron dalam PikiranRakyat, 2018). Berdasarkan wawancara yang dilakukan bulan April 2020 dengan seorang dosen senior yang masih aktif mengajar di Universitas Padjadjaran menyatakan bahwa dosen senior di masa pandemi saat ini tidak dapat mengajar secara langsung di hadapan mahasiswanya dengan cara menampilkan power point, menjelaskan materi pembelajaran yang secara langsung mendapat feedback dari mahasiswa.

Situasi pandemi saat ini menjadi tantangan bagi dosen dan mahasiswa yang harus melakukan pembelajaran daring, terutama bagi yang tidak terbiasa menggunakan teknologi internet. Dosen menghadapi berbagai tantangan dalam memberikan pengajaran yang efektif melalui pembelajaran daring. Mayoritas akademisi tidak memiliki pelatihan dalam pendidikan online (Mallillin et al., 2020). Bagi negara berkembang seperti Indonesia pembelajaran daring masih belum biasa dilakukan oleh tenaga pengajar seperti dosen. Beberapa penelitian menunjukkan bahwa kompetensi informasi, komunikasi, dan teknologi (ICT) tenaga pengajar di Indonesia tidak tersebar merata di seluruh wilayah (Widodo \& Riandi, 2013). Terlebih lagi, ada kesenjangan kualitas pendidikan di seluruh wilayah Indonesia, terutama antara Jawa dan luar Jawa, dan di antara kondisi-kondisi sosio-ekonomi (Azzizah, 2015; Muttaqin, 2018). Akses internet yang tidak merata, kesenjangan kualifikasi tenaga pengajar, dan kualitas pendidikan, serta kurangnya keterampilan ICT menjadi kerentanan dalam pembelajaran jarak jauh di Indonesia.

Kesiapan dosen dalam pembelajaran daring mengeksplorasi kerentanan mereka dalam menjalankan profesinya karena penyesuaian mereka terhadap teknologi dari setting kelas hingga setting pembelajaran daring, hal tersebut merupakan tantangan lain bagi para dosen di berbagai institusi pendidikan (Cutri \& Mena, 2020). Dalam situasi saat ini, dosen-dosen senior terpaksa memberikan pembelajaran daring tanpa dapat dibantu oleh asisten atau dosen-dosen junior dikarenakan sulitnya mendapatkan pelatihan penggunaan media pembelajaran daring secara langsung. Kemampuan dosen terbatas dalam menggunakan teknologi pada pembelajaran daring. Tidak semua dosen mampu mengoperasikan komputer atau gadget untuk mendukung kegiatan pembelajaran, baik secara tatap muka langsung dan pembelajaran daring. Sebagian besar dosen mampu mengoperasikan komputer, tetapi dalam hal pengoperasian yang terbatas dan sederhana. Keterbatasan penting lainnya adalah kurangnya pengembangan profesional yang memadai mengenai teknologi, sumber daya fisik yang terbatas, sumber daya yang tidak memadai, akses teknologi yang terbatas, kurangnya dukungan teknis, kompetensi dan kepercayaan diri (Hadijah \& Shalawati, 2017). Dalam sebuah penelitian (Napitupulu, 2020) mayoritas mahasiswa menilai bahwa dosen belum mampu menyampaikan materi PJJ, sebanyak 161 mahasiswa menjawab tidak puas, hanya 40 orang yang merasa puas dengan kemampuan dosen dalam menyampaikan materi PJJ. Kemampuan dosen terlibat aktif dan memberikan tambahan ilmu secara online yang berpengaruh dalam meningkatkan mutu pembelajaran (Karwati, 2014).

Keterbatasan dosen dalam memberikan pembelajaran daring secara PJJ disebabkan oleh beberapa faktor, diantaranya karena faktor usia sehingga memerlukan proses adaptasi yang memakan waktu, tidak adanya pelatihan tentang pembelajaran daring atau dikarenakan terbiasa menggunakan 
pembelajaran konvensional. Dosen senior yang merupakan generasi baby boomers pada saat ini adalah akademisi yang terbentuk dengan keterbatasan pengetahuan dan keterampilan teknologi komunikasi dan informasi. Tidak sedikit dosen dengan masa tugas di atas 30 tahun dengan usia di atas 50 tahun mengalami kesulitan menggunakan sarana dan prasarana berbasis teknologi, terutama komputer, laptop dan fasilitas media berbasis IT lainnya (Mulawarman, 2020). Dosen senior seringkali lambat dalam mengaplikasikan pembelajaran daring, mereka juga seringkali mengandalkan metode pembelajaran konvensional daripada mencoba belajar mengandalkan perangkat teknologi. Di sisi lain, dosen junior atau yang berusia muda lebih siap dan mahir dalam mengoperasikan perangkat teknologi untuk proses pembelajaran, mereka seringkali mengikuti perkembangan teknologi informasi dan mencoba berinovasi menggunakan perangkat teknologi untuk menunjang proses pembelajaran (Sauri et al., 2020)

Berdasarkan sebuah penelitian, pembelajaran jarak jauh terbukti menyulitkan bagi banyak dosen. Ketika universitas memutuskan untuk melakukan pembelajaran daring, beberapa akademisi berpikir bahwa hal ini merupakan keuntungan bagi mereka untuk dapat memunculkan ide dan mengerjakan suatu penelitian (Flaherty, 2020). Namun demikian pada kenyataannya untuk beberapa individu hal tersebut sulit dilakukan karena banyaknya hal yang harus dipikirkan dan dikerjakan secara bersama-sama di rumah. Seperti diketahui bahwa tugas dan kewajiban dosen tidak hanya mengajar namun mereka juga wajib melaksanakan dua tugas lainnya yang tercantum dalam Tri Dharma Pendidikan Tinggi yaitu penelitian, dan pengabdian. Selain melaksanakan pengajaran, dosen diharapkan dapat terus melakukan penelitian pada bidang keahliannya dan memberikan bimbingan kepada mahasiswa (Yuliawati, 2010). Sebagai seorang ilmuwan, dosen dituntut untuk dapat mempublikasikan hasil penelitiannya dalam jurnal ilmiah atau seminar nasional dan internasional sekalipun di masa pandemi COVID-19.

Mengubah kebiasaan lama menjadi kebiasaan baru tentu memerlukan waktu dan proses adaptasi. Dosen dan mahasiswa tentu memerlukan proses adaptasi untuk menyesuaikan proses pembelajaran dari metode konvensional ke metode daring. Proses adaptasi perubahan pembelajaran ini menuntut kesiapan dari para dosen khususnya dosen senior yang masih belum terbiasa dengan penggunaan teknologi untuk memberikan pembelajaran daring pada mahasiswa. Perubahan proses pembelajaran dari metode konvensional ke metode daring tentu berdampak positif dan juga negatif. Bagi dosen yang siap menghadapi perubahan tersebut, pembelajaran daring berdampak positif pada proses layanan pembelajaran, perkembangan teknologi informasi memberikan kemudahan terhadap akses pembelajaran. Namun bagi dosen yang tidak siap, pembelajaran daring tentu menjadi beban dan masalah yang disebabkan kebiasaan dosen selama ini terpusat pada metode pembelajaran konvensional.

Oleh karena itu, dilakukan penelitian yang bertujuan untuk menganalisis penyesuaian diri dosen senior dalam pembelajaran jarak jauh dalam masa pandemi COVID-19. Berdasarkan Schneiders (1999), penyesuaian diri adalah usaha yang mencakup respon mental dan tingkah laku individu, yaitu individu berusaha keras agar mampu mengatasi konflik dan frustrasi karena terhambatnya kebutuhan dalam dirinya, sehingga tercapai keselarasan dan keharmonisan dengan diri atau lingkungannya. Penyesuaian diri meliputi ketiadaan emosi yang berlebihan, ketiadaan mekanisme psikologis, dan perasaan frustrasi pribadi, pertimbangan rasional dan kemampuan mengarahkan diri (self-direction), kemampuan untuk belajar, kemampuan menggunakan pengalaman masa lalu, dan sikap realistik dan objektif terhadap pembelajaran jarak jauh. Dengan demikian rumusan masalah dalam penelitian ini adalah mengkaji bagaimana penyesuaian diri dosen senior dalam pembelajaran jarak jauh di masa pandemi COVID-19. 


\section{METODE PENELITIAN}

Penelitian ini menggunakan metode kualitatif dengan pendekatan fenomenologi. Dengan metode kualitatif diharapkan peneliti dapat menggali secara mendalam sebuah pengalaman sadar beberapa subjek penelitian yang berstatus dosen senior sebagai subjek yang terdampak COVID-19 dalam proses belajar mengajar.

Subjek pada penelitian ini adalah dosen-dosen senior yang melakukan pembelajaran jarak jauh di rumah. Pemilihan partisipan dilakukan dengan purposive sampling, dimana partisipan yang diambil adalah partisipan dengan karakteristik: (1) dosen, (2) telah mengajar selama lebih dari 30 tahun (Mulawarman, 2020) dan (3) usia di atas 53 - 71 tahun yang tergolong baby boomers (Ghufron, 2018)

Penelitian ini dilakukan pada saat pandemi COVID-19 bulan April-Juni 2020. Teknik pengambilan data dilakukan melalui wawancara mendalam dengan media telepon dan video call yang dilakukan selama 120 menit selama 2 hari per subjek. Pedoman wawancara mencakup pertanyaan mengenai penghayatannya terhadap pembelajaran jarak jauh yang dilakukan akibat COVID-19 serta adaptasi yang mereka lakukan terkait perubahan metode pembelajaran sesuai dengan teori penyesuaian diri Schneiders (1999). Hal ini dilakukan untuk menangkap secara mendalam bagaimana gambaran penyesuaian dosen senior terhadap pembelajaran jarak jauh akibat COVID-19.

Teknik analisis yang digunakan adalah thematic analysis yaitu metode analisis data kualitatif yang mengkaji data untuk mengidentifikasi tema-tema umum berdasarkan kesimpulan atau fitur signifikan dari data yang didapatkan (Howwit, 2010). Selanjutnya, dilakukan verifikasi terhadap hasil pengkodingan yang sudah dilakukan dengan melakukan peer review yang dilakukan oleh dua orang interrater. Selanjutnya peneliti melakukan revisi sesuai dengan yang sudah diberikan oleh interrater dan sudah didiskusikan bersama-sama.

\section{HASIL DAN PEMBAHASAN}

Dosen senior tergolong cukup banyak populasinya, namun tidaklah mudah untuk mendapatkan kesediaannya menjadi salah satu subjek penelitian ini. Dalam penelitian ini pendekatan yang digunakan adalah fenomenologi sehingga subjek bersedia untuk terbuka pada pengalamanpengalaman pribadi yang dimilikinya. Didapatkan empat subjek penelitian, yaitu:

\section{Tabel 1}

Profil Subjek Penelitian

\begin{tabular}{ccccc}
\hline & Subjek 1 & Subjek 2 & Subjek 3 & Subjek 4 \\
\hline Nama (Inisial) & PH & FUN & HS & ST \\
Jenis kelamin & P & P & L & P \\
Usia & 62 & 63 & 62 & 65 \\
Lamanya bekerja (tahun) & 34 & 35 & 32 & 37 \\
\hline
\end{tabular}

Seluruh partisipan merupakan dosen senior yang memiliki masa kerja lebih dari 30 tahun (Tabel 1). Melalui wawancara yang mendalam terhadap empat subjek penelitian yang berasal dari empat program studi yang berbeda, diperoleh pernyataan-pernyataan terkait penyesuaiannya dalam melaksanakan kegiatan pengajaran secara daring. 
Tabel 2

Tema dan Coding

\begin{tabular}{|c|c|c|c|c|}
\hline \multirow{2}{*}{ Tema } & \multicolumn{4}{|c|}{ Subjek } \\
\hline & $\mathbf{P H}$ & FUN & HS & ST \\
\hline $\begin{array}{l}\text { Emosi tidak } \\
\text { berlebihan }\end{array}$ & $\begin{array}{l}\text { Tenang } \\
\text { Sudah terbiasa } \\
\text { Dibantu oleh asisten }\end{array}$ & $\begin{array}{l}\text { Tidak nyaman } \\
\text { Sudah } \\
\text { mempersiapkan } \\
\text { Bosan }\end{array}$ & $\begin{array}{l}\text { Tidak nyaman } \\
\text { Marah }\end{array}$ & $\begin{array}{l}\text { Tenang } \\
\text { Sudah terbiasa } \\
\text { Dibantu oleh asisten } \\
\text { Bosan }\end{array}$ \\
\hline $\begin{array}{l}\text { Tidak ada } \\
\text { mekanisme } \\
\text { psikologis }\end{array}$ & $\begin{array}{l}\text { Mekanisme } \\
\text { pertahanan diri yang } \\
\text { dilakukan efektif }\end{array}$ & Rasionalisasi & Rasionalisasi & $\begin{array}{l}\text { Mekanisme } \\
\text { pertahanan diri yang } \\
\text { dilakukan efektif }\end{array}$ \\
\hline $\begin{array}{l}\text { Tidak ada } \\
\text { perasaan frustrasi }\end{array}$ & & & & \\
\hline $\begin{array}{l}\text { Pertimbangan } \\
\text { rasional dan self- } \\
\text { direction }\end{array}$ & $\begin{array}{l}\text { Melihat berbagai } \\
\text { jenis platform } \\
\text { pengajaran yang lebih } \\
\text { sesuai }\end{array}$ & $\begin{array}{l}\text { Tidak } \\
\text { mempertimbangk } \\
\text { an platform lain }\end{array}$ & $\begin{array}{l}\text { Tidak } \\
\text { mempertimbangk } \\
\text { an platform lain }\end{array}$ & $\begin{array}{l}\text { Melihat berbagai jenis } \\
\text { platform pengajaran } \\
\text { yang lebih sesuai }\end{array}$ \\
\hline $\begin{array}{l}\text { Kemampuan } \\
\text { untuk belajar }\end{array}$ & $\begin{array}{l}\text { Belajar penggunaan } \\
\text { media online }\end{array}$ & $\begin{array}{l}\text { Tidak } \\
\text { mempelajari dan } \\
\text { mencari tahu } \\
\text { media online }\end{array}$ & $\begin{array}{l}\text { Tidak } \\
\text { mempelajari dan } \\
\text { mencari tahu } \\
\text { media online }\end{array}$ & $\begin{array}{l}\text { Belajar penggunaan } \\
\text { media online }\end{array}$ \\
\hline $\begin{array}{l}\text { Kemampuan } \\
\text { menggunakan } \\
\text { pengalaman masa } \\
\text { lalu }\end{array}$ & $\begin{array}{l}\text { Mengganti metode } \\
\text { jika tidak efektif }\end{array}$ & $\begin{array}{l}\text { Tidak mengganti } \\
\text { metode meskipun } \\
\text { tidak efektif }\end{array}$ & $\begin{array}{l}\text { Tidak mengganti } \\
\text { metode meskipun } \\
\text { tidak efektif }\end{array}$ & $\begin{array}{l}\text { Mengganti metode } \\
\text { jika tidak efektif }\end{array}$ \\
\hline $\begin{array}{l}\text { Sikap realistik } \\
\text { dan objektif }\end{array}$ & $\begin{array}{lr}\text { Melanjutkan } & \text { blended } \\
\text { learning } & \\
\text { Mendapat } & \text { banyak } \\
\text { keuntungan } & \text { dari } \\
\text { WFH } & \end{array}$ & $\begin{array}{l}\text { Mendapat banyak } \\
\text { keuntungan dari } \\
\text { WFH }\end{array}$ & $\begin{array}{l}\text { Melanjutkan } \\
\text { blended learning }\end{array}$ & $\begin{array}{l}\text { Melanjutkan blended } \\
\text { learning } \\
\text { Mendapat banyak } \\
\text { keuntungan dari WFH }\end{array}$ \\
\hline
\end{tabular}

Schneiders (1999) menyatakan penyesuaian diri adalah usaha yang mencakup respon mental dan tingkah laku individu, yaitu individu berusaha keras agar mampu mengatasi konflik dan frustrasi karena terhambatnya kebutuhan dalam dirinya, sehingga tercapai keselarasan dan keharmonisan dengan diri atau lingkungannya. Konflik dan frustrasi muncul karena individu tidak dapat menyesuaikan diri dengan masalah yang timbul pada dirinya. Karakteristik penyesuaian diri menurut Schneiders (1999) adalah (Tabel 2):

\section{Tema 1: Ketiadaan emosi yang berlebihan}

Penyesuaian yang normal dapat diidentifikasi dengan tidak ditemukannya emosi yang berlebihan. Individu yang merespon masalah dengan ketenangan dan kontrol emosi memungkinkan individu untuk memecahkan kesulitan secara intelijen. Adanya kontrol emosi membuat individu mampu berpikir jernih terhadap masalah yang dihadapinya dan memecahkan masalah dengan cara yang sesuai. Ketiadaan emosi tidak berarti mengindikasikan abnormalitas tapi merupakan kontrol dari emosi.

Berdasarkan hasil wawancara yang telah dilakukan, keempat dosen menunjukkan ketiadaan emosi yang berlebihan. Mereka cukup dapat mengontrol emosinya terhadap perubahan yang terjadi karena pembelajaran jarak jauh (PJJ) yang mengharuskan mereka untuk melakukan kuliah secara daring. Hal tersebut mendukung mereka untuk dapat berpikir jernih dan mengatasi perubahan 
tersebut dengan cepat. Hasil wawancara menunjukkan bahwa dua dari mereka telah melakukan pembelajaran daring sebelumnya sehingga mereka tidak kaget dengan metode pembelajaran yang saat ini digunakan. Lalu satu subjek lainnya juga telah mempersiapkan bahan ajar untuk para mahasiswanya. Hal tersebut membuat ia tidak kerepotan untuk membagikan materi perkuliahan.

"Asisten saya sudah membuatkan google classroom sehingga sebelum Work From Home (WFH) pun kami sudah blended learning”. (Subjek PH)

"Sebelumnya saya juga sudah menggunakan media online dalam proses pembelajaran, tentu dibantu oleh asisten saya waktu itu. Jadi saat ini saya sudah cukup biasa dengan media online ini". (Subjek SK)

"Untung sebelumnya sudah bagi makalah dan buku, jadi mereka sudah punya bahan perkuliahan. Ya jadi memudahkan saya sih sekarang, jadi ga kaget”. (Subjek FUN)

Terdapat dua dosen yang pada awalnya merasa tidak nyaman ketika pembelajaran jarak jauh ditetapkan sehingga membuat mereka harus kuliah secara online. Dengan ketidaknyamanan yang dimiliki kedua subjek, membuat mereka cukup lambat dalam menyesuaikan terhadap perubahan yang terjadi.

"Waktu awal ga nyaman banget.. riweuh jadinya terus laptop saya kan ga bagus juga." (Subjek FUN)

"Saya masih lebih suka kuliah tatap muka daripada online seperti sekarang. Asisten saya juga ga banyak bantu, setengah semester saya serahkan pada asisten. Eh taunya dia juga ga bener, jadi mahasiswa protesnya ke saya. Saya kesal setengah semester itu kan udah bukan urusan saya harusnya, karena sudah dibagi. Saya sampai lapor ke Kaprodi terkait ini." (Subjek HS)

Dosen-dosen senior yang menjadi subjek penelitian telah mendekati masa pensiun, sehingga dua di antaranya sudah bosan dengan situasi pengajaran seperti saat ini yang mengharuskan kuliah secara online. Hal tersebut memengaruhi dosen dalam pengajaran yang diberikan pada mahasiswa, mereka kurang mengeksplorasi media online yang banyak tersedia.

"Saya mah kan udah mau pensiun, jadi suka bosan dan malas kalo mau daring, saya kan udah ngasih makalah dan buku jadi saya kasih tugas aja terus kumpulkan lewat e-mail. Nah kalau sidang saya pakai yang video call gitu." (Subjek FUN)

"Saya mah ga maksa lah saya ga beli paket zoom, jadi pakainya 40 menit sekali. Waktu itu saya pernah sampai harus $3 x$ gara-gara durasinya abis, kan udah mau pensiun ini jadi yaudah pakai yang ada aja." (Subjek SK)

\section{Tema 2: Ketiadaan mekanisme psikologis}

Penyesuaian yang normal dikarakteristikkan dengan mekanisme pertahanan diri yang efektif. Ketika usaha yang dilakukan gagal, individu mengakui kegagalannya dan berusaha mendapatkannya lagi merupakan penyesuaian diri yang baik dibandingkan melakukan mekanisme seperti rasionalisasi, proyeksi, kompensasi. Individu dengan penyesuaian diri yang buruk berusaha melakukan rasionalisasi dengan menimpakan kesalahan pada orang lain. 
Berdasarkan hasil wawancara didapatkan bahwa dua dosen melakukan rasionalisasi terhadap metode pembelajaran yang saat ini dilakukan. Metode yang digunakannya terbukti tidak efektif, hal tersebut didukung oleh feedback yang diberikan oleh mahasiswa. Subjek HS menyalahkan asistennya yang tidak membantu dalam pengajaran secara online.

"Saya mengajar sampai tengah semester saja pake WhatsApp (WA), sisanya diteruskan oleh asisten. Sebelum WFH juga saya sudah gunakan WA untuk kombinasi mengajar tatap muka dengan mahasiswa, saya ga akan mengubah kebiasaan, makanya saya pakai WA saja. Beberapa dari mahasiswa waktu itu ada yang memberi feedback kalau mereka lebih enak dengan cara melihat dosennya mengajar, dibandingkan hanya chat saja. Saya tetep pakai WA aja, kayanya mahasiswa yang lain juga ga protes dan komunikasi lancar kok. Asisten saya juga ga bener, tidak tanggung jawab dengan kelasnya yang sudah dibagi, dia emang harusnya bantu saya di kelas itu, tapi kan itu bukan tanggung jawab saya sekarang, saya udah selesai mengajarnya di setengah semester sebelumnya." (Subjek HS)

Subjek FUN yang kurang terampil dalam penggunaan media daring menyampaikan alasan laptop yang kurang baik, sehingga ia tidak dapat mengajar secara daring dengan optimal. Subjek masih melakukan pembelajaran yang tergolong konvensional dengan memberikan materi seperti makalah dan buku serta penugasan yang dikumpulkan via e-mail. Hal tersebut dinyatakan dalam kutipan berikut:

"Untung sebelumnya sudah bagi makalah dan buku, jadi mereka sudah punya bahan perkuliahan jadi saya kasih tugas aja terus kumpulkan lewat e-mail. Saya akan beli laptop baru aja... rumeuk. Laptop saya yang sekarang ga bagus jadi ga bisa di pake, sebelumnya juga saya pinjem yang suami." (Subjek FUN)

Sedangkan dua dosen lainnya tidak melakukan mekanisme psikologis. Ketika mereka dihadapkan pada kegagalan atau kesulitan dalam cara metode pengajaran yang telah berubah, mereka dapat mengakui kesulitannya dan mencoba mempelajari metode lainnya.

\section{Tema 3: Ketiadaan perasaan frustrasi pribadi}

Penyesuaian yang baik terbebas dari perasaan frustrasi pribadi. Perasaan frustrasi membuat sulit bereaksi normal terhadap masalah. Individu yang merasa frustrasi akan mengganti reaksi normal dengan mekanisme psikologis atau reaksi lain yang sulit dalam menyesuaikan diri seperti sering marah tanpa sebab ketika bergaul dengan orang lain. Penyesuaian diri yang normal ditandai dengan tidak adanya gejala depresi ataupun stres dalam menghadapi berbagai kesulitan ataupun masalah. Individu cenderung bersikap dan bereaksi secara wajar serta tidak menunjukkan perilaku yang menyimpang.

Berdasarkan hasil wawancara pada keempat subjek, tidak ditemukan pernyataan yang menyatakan bahwa mereka mengalami frustrasi terhadap perubahan pengajaran yang terjadi akibat COVID19. Keempatnya tidak menunjukkan gejala stres dan depresi yang signifikan dalam menghadapi kesulitan yang dialaminya. Hal tersebut didukung oleh pernyataan beberapa dosen bahwa mereka telah mendekati masa pensiun sehingga tidak ada achievement yang harus segera diraih, mereka telah menikmati cara pengajarannya saat ini. 
"Saya sekarang nothing to lose aja, sudah merasa cukup dengan pencapaian diri. Dalam hal mengajar saya selalu didampingi dosen milenial yang sangat terampil dengan teknologi, saya dibagian materi dan deliverynya..." (Subjek PH)

"Saya mah kan udah mau pensiun, jadi suka bosan dan malas kalo mau daring" (Subjek FUN)

"Saya kan udah mau pensiun, walau akan mengajukan NIDK sampai usia 70.., jadi yaudah pake materi yang ada, tinggal media ajarnya diserahkan ke dosen muda..” (Subjek SK)

\section{Tema 4: Pertimbangan rasional dan kemampuan mengarahkan diri (self-direction)}

Karakteristik menonjol dari penyesuaian normal adalah pertimbangan rasional dan kemampuan mengarahkan diri. Kemampuan individu menghadapi masalah, konflik, frustrasi menggunakan kemampuan berpikir secara rasional dan mampu mengarahkan diri dalam tingkah laku yang sesuai mengakibatkan penyesuaian normal. Kemampuan kognitif individu dalam mempertimbangkan konsekuensi-konsekuensi yang akan dihadapi dalam pengambilan keputusan dapat mengarahkan individu dalam bertindak. Individu yang mampu berpikir rasional dapat menghindarkan dirinya dari tindakan ataupun perilaku-perilaku menyimpang.

Berdasarkan hasil wawancara, beberapa dosen melakukan pertimbangan dalam mengambil keputusannya untuk bertindak. Melakukan pembelajaran secara daring sudah menjadi keharusan bagi semua dosen, sehingga penggunaan media online tidak dapat dihindarkan apalagi dengan pandemi COVID-19 saat ini. Begitu banyak media online yang dapat dimanfaatkan sebagai media pengajaran, di antaranya zoom, google meet, jitsi, spoon, podcast dll. Pada awal WFH, dosen senior memikirkan penggunaan media yang masih dapat dikendalikan atau di edit jika terjadi kesalahan penyampaian materi. Dosen PH mempertimbangkan beberapa metode dalam memberikan materi, seperti yang tertera dibawah:

"Saya mencoba merekam penyampaian materi secara audio, namun kemudian saya ingin yang lebih lagi, yaitu merekam penyampaian materi secara audio visual dengan latar musik, namun ketika mau diunggah saya menghadapi kesulitan, sehingga asisten saya membantu saya dengan membagi materi menjadi beberapa bagian dan diunggah melalui youtube.. sejak saat itu saya tidak mau melakukannya lagi.. kok repot ya..sampai akhirnya saya mempertimbangkan zoom." (Subjek PH)

Sedangkan dosen SK merasa berhasil dan nyaman dengan media audionya, namun saat ini SK telah mencoba berbagai platform yang dapat digunakan untuk metode pembelajaran secara online. Berikut penuturan yang diberikannya:

"Beberapa kali saya merekam materi dengan suara saja, jika gagal saya bisa ulang lagi.. Tapi sekarang saya udah mulai pakai zoom sih ternyata lebih mewadahi saya selaku dosen komunikasi untuk dapat berkomunikasi langsung dengan mahasiswa. Pakai zoom juga karena banyak rapat, webinar, kuliah yang harus pake zoom.” (Subjek SK)

Sedangkan dua dosen lainnya kurang mempertimbangkan media online lainnya untuk mengajar. Dalam kondisi pandemi ini akan sangat sulit jika dosen hanya mengandalkan cara pembelajaran yang konvensional dengan pemberian tugas saja, sehingga metode seperti itu cenderung tidak efektif bagi mahasiswa generasi saat ini. 
"Saya tetap pakai WA saja..saya ga mau jadi host pake zoom, takut dihack. Jadi saya mengajar sampai tengah semester saja pake WA, sisanya diteruskan oleh asisten. Beberapa dari mahasiswa waktu itu ada yang memberi feedback kalau penggunaan media online sudah menjadi lifestyle walau ada juga yang keberatan dengan kuota, makanya saya tetap pakai WA.” (Subjek HS)

\section{Tema 5: Kemampuan untuk belajar}

Penyesuaian yang normal dikarakteristikkan dengan belajar terus-menerus dalam memecahkan masalah yang penuh dengan konflik, frustrasi atau stres. Belajar merupakan proses kognitif yang sejatinya berlaku sepanjang hayat dan proses belajar yang dilakukan adalah untuk memecahkan masalah baik yang sedang ataupun yang akan dihadapi nantinya. Mampu untuk mempelajari pengetahuan yang mendukung apa yang dihadapi membuat pengetahuan yang diperoleh dapat dipergunakan untuk mengatasi permasalahan yang dihadapi.

Seiring berjalannya waktu terjadi perubahan media platform yang digunakan sebagai akibat dari feedback yang kurang baik dari mahasiswa terkait media online yang digunakan. Mahasiswa tidak merasa puas dengan penggunaan Whatsapp (WA), podcast, spoon juga Google classroom yang tanpa tatap muka. Berdasarkan wawancara yang telah dilakukan, mereka mengatakan:

“Akhirnya dosen ada yang mencoba menggunakan zoom, jitsi dan googlemeet yang tidak berbayar. Proses perpindahan media platform ini bukanlah hal yang mudah. Awalnya asisten yang invite melalui zoom mereka untuk mengajar. Tapi minggu-minggu berikutnya malu juga karena selalu difasilitasi oleh asisten. Terus ketika durasi penggunaan zoom habis, saya malu ga ngemodal banget. Muncul rasa tidak PD ketika mau bertindak sebagai host, ternyata tidak semudah itu untuk tampilkan sharescreen, admit mahasiswa yang hadir dan berbagai tugas yang dilakukan oleh seorang host. Belum lagi kalo laptopnya ngadat ga ada gambar atau ga ada suara, sharescreen juga bermasalah.. wah ribet.. Tapi akhirnya anak saya membantu saya untuk menggunakan zoom, hingga saat ini saya udah mulai terbiasa bahkan saya jadi berlangganan zoom" (Subjek PH)

"Saya berdua dengan suami dipandu oleh anak dan belajar bersama bagaimana menggunakan media online dengan lebih maksimal seperti zoom, karena mahasiswa menginginkan pertemuan yang "tatap muka" walau bermedia, sekarang saya udah bisa sendiri tanpa dibantu." (Subjek SK)

\section{Tema 6: Kemampuan menggunakan pengalaman masa lalu}

Kemampuan menggunakan pengalaman masa lalu merupakan usaha individu untuk belajar dalam menghadapi masalah. Penyesuaian yang normal membutuhkan penggunaan pengalaman masa lalu. Dalam menghadapi masalah, individu harus mampu membandingkan dengan pengalaman sebelumnya atau pengalaman orang lain sehingga pengalaman-pengalaman yang diperoleh dapat digunakan dalam mengatasi permasalahan yang dihadapi.

Dalam perubahan metode pembelajaran daring, dosen senior beberapa kali berganti metode pembelajaran karena dirasa kurang sesuai. Mereka juga mengalami perubahan metode di awal WFH hingga saat ini telah efektif dan nyaman bagi mereka. Mereka membandingkan pengalamannya sebelumnya yang tidak efektif untuk pengajaran bagi mahasiswa. Mahasiswa juga mengharapkan bahwa dosen memberikan pengajaran kuliah secara daring dengan tatap muka dibandingkan hanya memberi PPT atau tugas saja. Berdasarkan hasil wawancara, PH menyatakan bahwa ia telah beberapa kali mengganti metode pembelajaran jarak jauh yang saat ini dilakukan. Ia mengatakan: 
"Waktu itu saya pakai audio, lalu ingin menambah latar music agar lebih menarik, ternyata kesulitan saya untuk memasukkannya. Dari situ cari saya cara lain untuk memberikan materi pada mahasiswa. Akhirnya saya coba zoom, awalnya masih suka di invite oleh asisten. Tapi sekarang saya bisa menjadi terbiasa karena sudah berkali-kali pakai zoom. Mahasiswa lain ada yang komen kalau kelas seperti jauh lebih enak dibanding hanya diberi materi atau tugas aja seperti kelas lain." (Subjek PH)

"Mahasiswa menginginkan pertemuan yang "tatap muka” walau bermedia," (Subjek SK)

\section{Tema 7: Sikap realistik dan objektif}

Penyesuaian yang normal berkaitan dengan sikap yang realistik dan objektif. Sikap realistik dan objektif berkaitan dengan orientasi individu terhadap kenyataaan, mampu menerima kenyataan yang dialami tanpa konflik dan melihatnya secara objektif. Penyesuaian ini ditandai dengan pola pikir dan objektivitas individu dalam menilai sesuatu, individu mampu bertindak menerima dan menilai kenyataan lingkungan di luar dirinya secara objektif sesuai dengan pertimbanganpertimbangan rasional dan perasaan.

Berdasarkan hasil wawancara, WFH yang berimplikasi pada pembelajaran jarak jauh ternyata disyukuri oleh dosen senior yang menjadi subjek penelitian. Dengan PJJ, dosen tidak perlu lagi ke kampus untuk melaksanakan perkuliahan. Sebelum PJJ dosen harus bersegera ke ruang kelas menemui mahasiswa dan menyampaikan materi perkuliahan. Banyak waktu yang dihabiskan bahkan untuk memenuhi sebuah jadwal perkuliahan sekalipun. Hal ini tentu saja menjadi pelajaran bagi dosen senior untuk menjadikan PJJ ini sebagai bagian dari metode pembelajaran konvensional tatap muka. Berikut adalah pernyataan dari para dosen:

"Walaupun awalnya ribet, PJJ dengan media online akan saya lanjutkan untuk efisiensi waktu dan tenaga, juga biaya. Situasi ini memang memaksa kita untuk secara sesungguhnya berperilaku lebih praktis." (Subjek PH)

"PJJ membuat fisik tidak terlalu lelah, saya akan lanjutkan melalui blended learning di semester mendatang." (Subjek SK).

"Enak juga PJJ ya, jadi banyak waktu di rumah untuk bisa mengerjakan hal lain. Emang hidup ini harus siap dengan situasi dan kondisi yang berubah sesuai dengan perkembangan masyarakat dunia. ”. (Subjek FUN)

"Saya masih lebih suka kuliah tatap muka, tapi kedepan kalo sudah normal, boleh juga kuliah dari rumah gunakan media online.". (Subjek HS)

Pandemi COVID 19 memang mengubah tatanan kehidupan di berbagai bidang tidak kecuali bidang pendidikan. Dosen senior yang termasuk dalam kategori baby boomers adalah mereka yang lahir pada tahun 1950 - 1960an, dimana teknologi informasi dan komunikasi masih sangat terbatas dibandingkan saat ini. Bagi dosen senior, begitu banyak hal baru yang dihadapi terutama ketika menghadapi mahasiswa yang termasuk dalam kategori generasi milenial. Namun pada akhirnya dosen senior dapat menerima perubahan ini sebagai sebuah keniscayaan yang harus terus dijalani. Kesiapan dari pendidik wajib dikuatkan, bukan hanya memenuhi persyaratan untuk bisa menyelenggarakan, namun juga memiliki wawasan keilmuan yang cakap. Pemaksaan untuk keluar dari zona nyaman pada dosen senior hendaknya dibarengi dengan penciptaan teknologi yang sistem pengoperasiannya user friendly (Watie \& Fanani, 2019). Maka dosen senior perlu diberikan sosialisasi mengenai perubahan metode pembelajaran dan berbagai media online dalam pelaksanaan pembelajaran jarak jauh. Dengan begitu dosen senior akan lebih memahami dan menerima perubahan dan perkembangan teknologi yang ada dan dapat mengikutinya. 
Ketersediaan beragam aplikasi yang dapat digunakan dalam pembelajaran jarak jauh, seperti WhatsApp, Google Meet, Zoom dan sebagainya telah menimbulkan tantangan baru khususnya dosen senior. Setiap aplikasi mempunyai karakteristik khusus yang akan mempengaruhi interaksi antara mahasiswa dan dosen. Kekhawatiran utama adalah dampak dari aplikasi tersebut terhadap kualitas hasil pembelajaran. Aplikasi seperti Zoom misalnya yang memiliki fitur lebih kaya dan interaktif tentu akan memberikan hasil yang lebih baik dibandingkan WhatsApp. Pengajar harus memahami karakteristik teknologi yang digunakan dalam pembelajaran jarak jauh, terutama terkait pengetahuan atas kelebihan dan kekurangan aplikasi yang digunakan. Pembuatan materi pengajaran tentu akan mengacu kepada kapasitas dan kapabilitas dari media aplikasi yang digunakan.

Mendikbud Nadiem Makarim mengatakan bahwa perlu mempertimbangkan tiga aspek vital untuk memastikan pelaksanaan pembelajaran jarak jauh tidak memperluas kesenjangan sosial. Tiga aspek digital tersebut adalah ketersediaan infrastruktur digital, keterampilan digital, dan karakteristik teknologi (Triwibowo, 2020). Sebuah studi di Amerika Serikat (Clark, 2009) menggambarkan bahwa keterampilan digital terkait erat dengan generasi dan usia. Generasi milenial dianggap lebih adaptif dan terampil menggunakan teknologi digital ketimbang generasi orang tuanya. Terdapat hasil penelitian yang menyatakan bahwa dosen senior tetap beradaptasi dengan cara terus belajar, sembari melaksanakan pembelajaran secara sinkronus menggunakan aplikasi digital lainnya seperti WhatsApp dan aplikasi video conference (Google Meet dan Zoom Meeting). Sementara untuk sistem pembelajaran daring, dosen senior meminta bantuan kepada dosen muda untuk menginputkan konten-konten tersebut ke dalam daring. Namun secara prinsip, berbagai kebutuhan pelaksanaan pembelajaran seperti rencana pembelajaran semester, bahan ajar, media pembelajaran, soal ujian, bahan tugas tetap disediakan oleh dosen senior. Hal ini dilakukannya untuk pencapaian tujuan pembelajaran tetap berlangsung di masa pandemi COVID19 (Fernandes et al., 2021). Kesenjangan generasi yang berkorelasi dengan keterampilan digital bisa termanifestasi dalam pembelajaran jarak jauh, ketika dosen yang gagap teknologi tidak akan mampu mengelola pembelajaran. Oleh karena itu, dalam menghadapi tuntutan pengajaran jarak jauh, dosen senior sangat membutuhkan bantuan dari pihak lain. Semua subjek mengakui peran anak yang sangat besar dalam menghadapi rasa frustrasi, dan stress menghadapi waktu perkuliahan. Anak yang merupakan generasi milenial dengan sangat mudah mengoperasikan aplikasi berbagai platform media pengajaran. Selain itu dosen junior yang juga berperan dalam "membimbing" dosen seniornya dalam menggunakan media online.

Media digital memiliki keterbatasan dalam memberikan isyarat non-verbal dan juga kecepatan umpan balik yang dapat mengganggu komunikasi selama pembelajaran. Perubahan metode tatap muka di kelas menjadi daring membutuhkan adaptasi dan perubahan, terutama dari sisi penyiapan materi dan interaksi. Pengajar yang tidak memiliki keterampilan digital dan pengetahuan atas karakteristik teknologi yang memadai akan terhambat sehingga tidak bisa mencapai tujuan pembelajaran yang ditetapkan. Dosen yang tidak terbiasa atau familiar dengan daring tentu akan kesulitan. Kadang kuliah memakai WhatsApp Group sudah dianggap kuliah daring. Masalahnya pembelajaran jarak jauh dengan daring membutuhkan pengetahuan teknis untuk mengirim materi dan menjawab beberapa pertanyaan yang ada dalam sistem tersebut. Untuk itu tidak semua dosen akan mudah melaksanakan hal tersebut khususnya dosen senior.

\section{KESIMPULAN DAN SARAN}

Dari hasil dan pembahasan yang sudah dijelaskan, maka diperoleh kesimpulan bahwa penelitian ini menunjukkan adanya proses penyesuaian diri yang dialami berbeda dari setiap dosen senior terkait pembelajaran jarak jauh di masa pandemi COVID-19. Sesuai dengan teori Schneiders (1999), secara keseluruhan dosen senior dalam penelitian ini cukup menunjukkan penyesuaian diri 
yang baik terhadap PJJ meskipun terdapat beberapa kendala yang menyertai. Mereka berusaha untuk dapat menghadapi perubahan metode pembelajaran akibat COVID-19 ini. Dengan keterbatasan dosen senior dalam menggunakan teknologi membuat mereka pun terbatas dalam mengeksplorasi berbagai media online yang dapat digunakan untuk metode PJJ. Kesulitan yang dihadapi oleh dosen senior dapat diatasi dengan cukup baik meskipun kadang membuat mereka emosi dan menyalahkan orang lain. Disamping itu dosen senior yang telah mendekati masa pensiun tidak mengalami frustrasi saat melakukan PJJ ini karena dosen senior selalu didampingi oleh asisten yang membantunya menggunakan media online dan telah memiliki gaya pengajaran masing-masing yang mereka nikmati sehingga tidak menimbulkan stress atau depresi. Mereka juga menyadari bahwa metode pembelajaran jarak jauh ini, dapat menjadi salah satu pilihan untuk proses pengajaran ke depannya.

Saran pada penelitian selanjutnya, karena jumlah partisipan pada penelitian ini yang tergolong kecil diharapkan menambah jumlah partisipan sehingga hasil penelitian dapat lebih digeneralisasikan. Kemudian saran berikutnya, yaitu mempertimbangkan faktor-faktor di luar tugas dan kewajiban dosen seperti aktivitas sehari-hari yang dapat memengaruhi penyesuaian diri dosen dalam melakukan pembelajaran jarak jauh. Lalu saran bagi pemerintah atau institusi perguruan tinggi untuk menyelenggarakan pelatihan terkait pembelajaran daring, mengenalkan berbagai media atau aplikasi yang dapat digunakan, dan melakukan kombinasi team teaching antara dosen senior dan dosen junior agar pembelajaran daring semakin efektif dan inovatif.

\section{Ucapan Terima Kasih (acknowledgement)}

Peneliti mengucapkan terima kasih kepada seluruh partisipan yang telah bersedia meluangkan waktunya untuk mengikuti penelitian ini. Ucapan terima kasih peneliti sampaikan juga kepada seluruh pihak yang terlibat khususnya fakultas, dosen pengampu mata kuliah, dan dosen pembimbing yang telah mengizinkan peneliti untuk melakukan penelitian dan pengambilan data kepada para dosen senior.

\section{REFERENSI}

Azzizah, Y. (2015). Socio-economic factors on Indonesia education disparity. International Education Studies, 8(12), 218-230. https://doi.org/10.5539/ies.v8n12p218

BBC. (2020, Maret 11). Coronavirus: What is a pandemic and why use the term now? https://www.bbc.com/news/health-51358459

Budiargo, D., Sujono, F. K., \& Dotulong, C. (2020, n.d). Belajar jarak jauh. Podcast Digital. https://podcasts.apple.com/id/podcast/seputar-covid-19-belajar-jarakjauh/id1485001880?i=1000468944360

Clark, L. S. (2009). Digital media and the generation gap. Information, Communication \& Society, 12(3), 388-407. https://doi.org/10.1080/13691180902823845

Cutri, R. M., \& Mena, J. (2020). A critical reconceptualization of faculty readiness for online teaching. Distance Education, 361-380. https://doi.org/10.1080/01587919.2020.1763167

Fernandes, R., Ananda, A., Montessori, M., Firman, Putra, E. V.,, Naldi, H., \& Fitriani, E. (2021). Adaptasi dosen digital immigrant terhadap pelaksanaan pembelajaran pada masa pandemi Covid-19. Jurnal Socius: Journal Of Sociology Research And Education, 8(1). https://doi.org/10.24036/scs.v8i1.298

Flaherty, Colleen. (2020, Maret 24). Working from home during Covid-19 proves challenging for faculty member. https://www.insidehighered.com/news/2020/03/24/working-homeduring-covid-19-proves-challenging-faculty-members 
Hadijah, S., \& Shalawati, S. (2017). Investigating teacher 'barrier to ICT (Information Communication Technology) integration in teaching english at Senior High School in Pekanbaru. Proceedings of ISELT FBS Universitas Negeri Padang, 5, 302-310. http://ejournal.unp.ac.id/index.php/selt/article/view/8019

Howitt, D. (2010). Introduction to Qualitative Research Methods in Psychology 3rd ed. Pearson. Hrastinki, S. (2008). Asynchronous and synchronous e-learning. Educause Quarterly, 31(4), 5155.

Karwati, E. (2014). Pengaruh pembelajaran elektronik (e-learning) terhadap mutu belajar mahasiswa. Jurnal Penelitian Komunikasi, 17(1), 41-54.

Kaur, G. (2020). Digital Life: Boon or bane in teaching sector on COVID-19. CLIO an Annual Interdisciplinary Journal of History, 6(6), 416-427.

Kominfo. (2020, Mei 21). Pandemi Covid-19 momentum adaptasi pendidikan era 4.0. https://www.kominfo.go.id/content/detail/26635/pandemi-covid-19-momentumadaptasi-pendidikan-era-40/0/berita

Mulawarman, W. G. (2020). Persoalan dosen dan mahasiswa masa pandemik covid 19: Dari gagap teknologi hingga mengeluh boros paket data. Prosiding Seminar Nasional Hardiknas, 1, $37-46$.

Muttaqin, T. (2018). Determinants of unequal access to and quality of education in Indonesia. The Indonesian Journal of Development Planning, 2(1), 1-20. https://doi.org/10.36574/jpp.v2i1.27

Mailizar, Almanthari, A., Maulina, S., \& Bruce, S. (2020). Secondary school mathematics teachers' views on e-learning implementation barriers during the Covid-19 pandemic: The case of Indonesia. Eurasia Journal of Mathematics, Science and Technology Education, 16(7), 1860.

Moleong, J L. (2009). Metode penelitian kualitatif. PT. Remaja Rosdakaya.

Napitupulu, R. M. (2020). Dampak pandemi Covid-19 terhadap kepuasan pembelajaran jarak jauh. $\begin{array}{lllll}\text { Jurnal Inovasi Teknologi } & \text { Pendidikan. }\end{array}$ https://doi.org/10.21831/jitp.v7i1.32771

PikiranRakyat. (2018, Februari 28). Indonesia miliki 113.965 dosen milenial. https://www.pikiranrakyat.com/pendidikan/pr-01294106/indonesia-miliki-113965-dosen-milenial-420337

Purwanto, A., Pramono, R., Asbari, M., Hyun, C. C., Wijayanti, L. M., Putri, R. S., \& Santoso, P. D. (2020). Studi eksploratif dampak pandemi COVID-19 terhadap proses pembelajaran online di sekolah dasar. Jurnal EduPsyCouns, 2(1), 1-12.

Sauri, S., Munawaroh, T., Riswanto, D., \& Nurbani. (2020). Pembelajaran virtual pada masa pandemic Covid-19: Tantangan dan solusi permasalahan. Civics Education And Social Science Journal(Cessj), 2(2). https://doi.org/10.32585/cessj.v2i2.1129

Schneiders. (1999). Personal adjustment and mental health. Holt Rinehart and Winston Inc.

Watie, E., \& Fanani, F. (2019). Memahami permasalahan komunikasi dalam sistem pembelajaran jarak jauh (online) dalam pendidikan tinggi ilmu komunikasi menghadapi revolusi industri 4.0. Buku Litera Yogyakarta.

Weiser, O., Blau, I., \& Alkalai, E.Y. (2018) How do medium naturalness, teaching-learning interactions and students personality traits affect participation in synchronous e-learning? The Internet and Higher Education, 37, 40-51. https://doi.org/10.1016/j.iheduc.2018.01.001

WHO. (2020, n. d.). Coronavirus disease (COVID-19): Overview. https://www.who.int/healthtopics/coronavirus\#tab=tab_1

Widodo, A., \& Riandi. (2013). Dual-mode teacher professional development: challenges and revisioning future TPD in Indonesia. Teacher Development, 17(3), 380-392. https://doi.org/10.1080/13664530.2013.813757 
Yuliawati, S. (2012). Kajian implementasi tri dharma perguruan tinggi sebagai fenomena pendidikan tinggi di Indonesia. [Thesis, Universitas Muhammadiyah Prof. Dr. Hamka]. 